\title{
The Effect of Freeze Drying Using Different Media and Storage Temperatures on Some Parameters of Buffalo Bull Spermatozoa
}

\author{
M.I. Shahba*, R.I. El-Sheshtawy", A.I. El-Azab ${ }^{* *}$, A.E. \\ Abdel-Ghaffar ${ }^{* *}$, Maha S. Ziada ${ }^{* * *}$ and A.A. Zaky \\ *Animal Reproduction and AI Department, Veterinary Division, \\ National Research Centre, ${ }^{* *}$ Theriogenology Department, \\ Faculty of Veterinary Medicine, Benha University and ${ }^{* * *}$ AI \\ and Embryo Transfere Research Department, Animal \\ Reproduction Research Institute, Al-Haram, Cairo, Egypt.
}

\begin{abstract}
7 HE PRESENT study was designed to display the effect of freezedrying (lyophilization) technique using different freeze-drying media and storage temperatures on some parameters of buffalo bull spermatozoa. The semen samples were collected once weekly from five mature buffalo bulls maintained in Animal Reproduction Research Institute, Ministry of Agriculture, Al- Haram, Giza, Egypt. Samples were allocated into two portions; the first one was cryopreserved in Tris-Fructose-Egg yolk-Glycerol, while the second portion was immediately freeze-dried. These two portions were exposed to the same technical procedures. The freeze-dryer set was programmed at $55^{\circ} \mathrm{C}$ and $0.001 \mathrm{mbar}$ pressure. The media tested were: EGTA solution, EDTA solution, TCM199 with Hanks salts enriched with $10 \%$ fetal calf serum (FCS) and TCM199 with Hanks salts enriched with $10 \%$ FCS and $0.2 \mathrm{M}$ trehalose. The storage temperatures experienced were $\left(4,-20,-80^{\circ} \mathrm{C}\right)$. The efficiency of each medium and storage temperature on some sperm parameters was explored. Our results revealed no motility either in raw or frozen-thawed spermatozoa after freeze-drying. In case of raw and frozen-thawed semen; with no respect to storage temperatures, the best freeze-dried sperm parameters were observed in TCM-Trehalose medium, while the best storage temperature was $\left(-80^{\circ} \mathrm{C}\right)$ followed by $\left(-20^{\circ} \mathrm{C}\right)$ with no respect to the type of freeze-drying media. From the present study, it was concluded that the freeze-drying medium containing trehalose could preserve efficiently components of buffalo bull spermatozoa, especially the acrosome, while the storage temperature $\left(-80^{\circ} \mathrm{C}\right)$ and $(-$ $20^{\circ} \mathrm{C}$ ) were the best for storage of freeze-dried buffalo bull spermatozoa.
\end{abstract}

Keywords: Buffalo, freeze-drying, EGTA, EDTA, Trehalose, acrosome.

The first trial to conserve sperm using dehydration was documented by Polge et al. (1949) using fowl sperm; although sperm appeared motile after rehydration, their fertilizing capacity was not assessed. Trials had been proceeded to freeze-dry mammalian sperm without any satisfactory results (Sherman, 1954 and Bialy \&

Corresponding author: R.I. El-Sheshtawy E-mail address: rielsheshtawy@gmail.com 
Smith, 1957). The first recorded birth following AI with freeze-dried sperm was reported in rabbit (Yushchenko, 1957). Development of freeze-drying aimed to preserve biologically active materials such as enzymes, pharmaceutical materials (e.g. antibiotics) and others (Keskintepe et al., 2002, Kusakabe et al., 2004). Furthermore, it has been used to conserve cells, owing to its capability to hinder water via ice sublimation (Polge et al., 1949). Although, more than 40-50\% of sperms are sensitive to damage during the freezing process, freeze-drying could be considered as an alternative process for preservation of sperms. Species diversity in susceptibility to preservation methods must be taken in consideration during our judgment on novel methods used for preservation of buffalo bull spermatozoa. For that, the sperm evaluation parameters outputs as a result of freeze-drying process may differ from one species to another. Our study on freeze-drying of buffalo bull spermatozoa misses the available literatures. Nowadays, a great research attention has been paid to freeze-drying of sperm. As compared to ordinary cryopreservation methods, Freezedrying offers low cost, no requirement to liquid nitrogen, little space needs for sperm storage and a reliable and low costly method of sperm transport (Gil et al., 2014). There's obvious success in production of offspring with freeze-dried sperm following the application of ICSI in animals (Wakayama et al., 1998, Liu et al., 2004). Freezedrying provided a new approach for storage and transportation of freeze-dried sperm at $4^{\circ} \mathrm{C}$ or room temperature $\left(25{ }^{\circ} \mathrm{C}\right)$, with many benefits for preservation of spermatozoa from animals (Kwon et al., 2004). One of the important challenges with any preservation method is the degree of cellular damage. Regardless of the protocol applied, cryopreservation has a damaging effect on sperm resulting in reduction of both motility and fertilizing capacity (Critser et al., 1987). Therefore, in spite of apparent reduction in motility, cells still viable and characterized by normal nucleus and centrosome integrity which are essential for the success of ICSI (Choi et al., 2011). Although freeze-drying was focused on proper preservation of structural and functional sperm characteristics, an intact sperm nucleus is a necessary part for success of embryo production (Wakayama and Yanagimachi, 1998, Kusakabe et al., 2001). Many trials were carried out to protect sperm structures during freeze-drying via various protecting substances, e.g. albumin (Wakayama and Yanagimachi, 1998, Wakayama et al., 1998), EGTA (Kusakabe et al., 2001 and Kaneko et al., 2003), EDTA (Kaneko and Serikawa, 2012) and trehalose (McGinnis et al., 2005). The main target of the current study was to investigate the effect of freeze-drying using different media and storage temperatures on some parameters of buffalo bull spermatozoa.

\section{Material and Methods}

\section{Semen collection and evaluation}

Five mature buffalo bulls, kept at Animal Reproduction Research Institute, Ministry of Agriculture, were implemented in this study. Semen was collected by using the artificial vagina once weekly $(n=3$, within 24 replicate). Immediately after collection, semen was evaluated. Only semen samples with $>80 \%$ motility and $<10 \%$ morphologically abnormal sperm were used for this study. 
Freeze-drying media

Mediuml: $10 \mathrm{mmol} / \mathrm{L}$ Tris-HCl buffered supplemented with $50 \mathrm{mmol} / \mathrm{L}$ of each $\mathrm{NaCl}$ and EGTA [ethyleneglycol-bis (b-aminoethyl ether)- $N, N, N^{\prime} N^{\prime}$ tetraacetic acid] with a final $\mathrm{pH}$ adjusted to 8.2.

Medium 2: $10 \mathrm{mmol} / \mathrm{L}$ Tris and $1 \mathrm{mmol} / \mathrm{L}$ EDTA with a final $\mathrm{pH}$ adjusted to 8.2.

Medium 3: TCM 199 with Hank's salts (Gibco Life Technologies Inc., Grand Island, NY, USA) supplemented with 10\% (v/v) FCS (Gibco Life Technologies Inc.).

Medium4: TCM 199 with Hank's salts supplemented with 10\% (v/v) FCS and $0.2 \mathrm{~mol} / \mathrm{L}$ trehalose.

All the media were designed according to Martins et al. (2007) except medium 2 was designed according to Kaneko and Serikawa (2012).

\section{Experimental design}

Ejaculates collected weekly were pooled, and processed in two portions: First one was cryopreserved with Tris-Fructose-Egg yolk-Glycerol extender as described by Foote (1970) with a total concentration of $30 \times 10^{6}$ sperm $/ 0.5 \mathrm{~mL}$ to be freeze-dried with the different media used in this study. The second one was freeze-dried immediately with the different media used in this study. According to Abdalla et al. (2009) semen samples were centrifuged in a percoll gradient (45-90\%) for $20 \mathrm{~min}$ at $700 \times \mathrm{g}$ to remove seminal plasma. Subsequently, sperms were washed twice in Tyrode's albumen lactate pyruvate (TALP) (Parrish et al., 1995) to remove percoll remains and allocated into the four media 1- 4, respectively.

\section{Sperm freeze-drying}

Samples were diluted in all experimental media, placed in tubes of $1.5 \mathrm{ml}$ and kept at room temperature for $30 \mathrm{~min}$. Sperm cell suspensions were cooled in liquid nitrogen vapor (approximately $-80^{\circ} \mathrm{C}$ for $1 \mathrm{~h}$ ), by keeping the tubes at a distance of $5 \mathrm{~cm}$ from liquid nitrogen surface before plunged into it. Frozen samples were immediately inserted into a programmable freeze-dryer stabilized at $\left(-55^{\circ} \mathrm{C}\right)$ and $0.001 \mathrm{mbar}$ pressure. After $24 \mathrm{hrs}$ of freeze-drying, the tubes containing the samples were covered with aluminum foil and stored for 3 months at different temperatures, $4^{\circ} \mathrm{C},-20^{\circ} \mathrm{C}$ and $-80^{\circ} \mathrm{C}$.

\section{Rehydration}

Freeze-dried sperm samples were re-hydrated by adding $100 \mu \mathrm{L}$ of milli-Q water at room temperature.

\section{Sperm assessment}

Sperm motility

A drop of sperm suspension from each treatment was placed on a pre-warmed slide $\left(37^{\circ} \mathrm{C}\right)$ and covered with cover slip. Individual progressive forward motile sperm subjectively was assessed by using phase contrast hot stage $\left(37^{\circ} \mathrm{C}\right)$ microscope set at magnification of $400 \times$ Visual motility was assessed microscopically with closed circuit television in 5-6 fields each slide. 
Sperm morphology

Smears were stained with Eosin-Nigrosin (Campbell et al., 1956) morphologically abnormal sperm percent. A total of 200 sperm cells will examined randomly.

Sperm membrane integrity

The hypo osmotic swelling test (HOST) was performed as described by (Jeyendran et al., 1984). The swollen spermatozoa characterized by coiling of the tail are considered to have an intact plasma membrane.

Sperm viability and Percentage of normal acrosomes

The dual staining procedures with Trypan Blue Giemsa stain (TBG) was performed as described by (Kovács and Foote, 1992). Sperm with no blue staining and a purple acrosome were considered viable (Way et al., 1995).

\section{Statistical analysis}

The obtained data were tabulated and computed for statistical analysis using the SAS computerized program v. 9.2 (SAS, 2008) to calculate the analysis of variance (ANOVA) for the different parameters. The obtained results, for the different semen parameters in different experiments, were expressed in mean \pm standard errors of mean. Differences between means were compared with the LSD procedure at least at $P<0.05$.

TABLE 1. Effect of freeze-drying media and storage temperature on morphology (\%) of raw buffalo spermatozoa after freeze-drying.

\begin{tabular}{|c|c|c|c|c|c|c|}
\hline \multirow{2}{*}{$\begin{array}{c}\text { Storage } \\
\text { temperature } \\
\left({ }^{\circ} \mathrm{C}\right)\end{array}$} & \multicolumn{4}{|c|}{ Type of media } & \multirow{2}{*}{$\begin{array}{c}\text { Overall } \\
\text { mean }\end{array}$} & \multirow{2}{*}{ Significance } \\
\hline & Tris-EGTA & $\begin{array}{c}\text { Tris- } \\
\text { EDTA }\end{array}$ & TCM & $\begin{array}{c}\text { TCM- } \\
\text { Trehalose }\end{array}$ & & \\
\hline+4 & $24.67 \pm 1.76$ & $21.67 \pm 2.90$ & $23.33 \pm 2.85$ & $27.33 \pm 2.90$ & $24.17^{\mathrm{A}}$ & \multirow{5}{*}{0.0032} \\
\hline-20 & $18.67 \pm 1.76$ & $21.33 \pm 2.60$ & $19.33 \pm 1.20$ & $19.00 \pm 3.21$ & $19.58^{\mathrm{B}}$ & \\
\hline-80 & $28.00 \pm 3.60$ & $25.67 \pm 3.18$ & $28.00 \pm 3.21$ & $27.00 \pm 3.46$ & $27.58^{\mathrm{A}}$ & \\
\hline $\begin{array}{c}\text { Overall } \\
\text { mean }\end{array}$ & $23.78^{\mathrm{a}}$ & $22.89^{\mathrm{a}}$ & $23.56^{\mathrm{a}}$ & $24.44^{\mathrm{a}}$ & & \\
\hline Significance & \multicolumn{5}{|c|}{0.9251} & \\
\hline
\end{tabular}

Interaction significance LSD $=0.8372$

Values within the same column with different letters differed significantly at least at $\mathrm{p}<0.05$

\section{Results}

Our results revealed no motility either in raw or frozen-thawed spermatozoa after freeze-drying. In case of raw semen; with no respect to storage temperatures, the best freeze-dried sperm parameters were observed in TCM-Trehalose medium as represented by sperm membrane integrity (Table 2) and acrosome status (Table 4) (64.56 and 66.22) respectively and with no respect to type of $\left(-80^{\circ} \mathrm{C}\right)$ followed by $\left(-20^{\circ} \mathrm{C}\right)$ as observed in sperm 
membrane integrity (Table 2) (68.92 and 58.50) respectively and sperm viability (Table 3) (82.75 and 76.92) respectively. In case of frozen-thawed semen; with no respect to storage temperatures the best freeze-dried media was TCM-Trehalose medium as represented by sperm morphology (Table 5) and viability (Table 7) (21.33 and 74.78) respectively while the best storage temperature was $\left(-80^{\circ} \mathrm{C}\right)$ followed by $\left(-20^{\circ} \mathrm{C}\right)$ with no respect to the type of media as showed in sperm membrane integrity (Table 6) (62.17 and 56.83) respectively and acrosome status (Table 8) (66.17 and 56.33) respectively.

TABLE 2. Effect of freeze - drying media and storage temperature on membrane integrity $(\%)$ of raw buffalo spermatozoa after freeze-drying.

\begin{tabular}{|c|c|c|c|c|c|c|}
\hline \multirow{2}{*}{$\begin{array}{c}\text { Storage } \\
\text { temperature } \\
\left({ }^{\circ} \mathbf{C}\right)\end{array}$} & \multicolumn{4}{|c|}{ Type of media } & \multirow{2}{*}{$\begin{array}{c}\text { Overall } \\
\text { mean }\end{array}$} & \multirow{2}{*}{ Significance } \\
\hline & $\begin{array}{c}\text { Tris- } \\
\text { EGTA }\end{array}$ & $\begin{array}{l}\text { Tris- } \\
\text { EDTA }\end{array}$ & TCM & $\begin{array}{c}\text { TCM- } \\
\text { Trehalose }\end{array}$ & & \\
\hline+4 & $56.67 \pm 2.40$ & $54.67 \pm 2.02$ & $51.33 \pm 1.76$ & $58.00 \pm 2.64$ & $55.17^{\mathrm{B}}$ & \multirow{3}{*}{0.0001} \\
\hline-20 & $\begin{array}{l}53.67 \pm 3.48 \\
67.33 \pm 3.75\end{array}$ & $\begin{array}{l}62.33 \pm 4.05 \\
69.67 \pm 4.05\end{array}$ & $\begin{array}{l}54.67 \pm 2.33 \\
66.33 \pm 4.05\end{array}$ & $\begin{array}{l}63.33 \pm 3.18 \\
72.33 \pm 3.75\end{array}$ & $\begin{array}{l}58.50^{\mathrm{B}} \\
68.92^{\mathrm{A}}\end{array}$ & \\
\hline Overall mean & $59.22^{\mathrm{ab}}$ & $62.22^{\mathrm{a}}$ & $57.44^{\mathrm{b}}$ & $64.56^{\mathrm{a}}$ & & \\
\hline Significance & \multicolumn{5}{|c|}{0.0579} & \\
\hline
\end{tabular}

Interaction significance LSD $=0.7802$

Values within the same column with different letters differed significantly at least at $\mathrm{P}<0.05$.

TABLE 3. Effect of freeze-drying media and storage temperature on viability (\%) of raw buffalo spermatozoa after freeze-drying.

\begin{tabular}{|c|c|c|c|c|c|c|}
\hline \multirow{2}{*}{$\begin{array}{c}\text { Storage } \\
\text { temperature } \\
\left({ }^{\circ} \mathbf{C}\right)\end{array}$} & \multicolumn{4}{|c|}{ Type of media } & \multirow{2}{*}{$\begin{array}{c}\text { Overall } \\
\text { mean }\end{array}$} & \multirow{2}{*}{ Significance } \\
\hline & $\begin{array}{l}\text { Tris- } \\
\text { EGTA }\end{array}$ & $\begin{array}{l}\text { Tris- } \\
\text { EDTA }\end{array}$ & TCM & $\begin{array}{c}\text { TCM- } \\
\text { Trehalose }\end{array}$ & & \\
\hline+4 & $72.33 \pm 2.96$ & $73.67 \pm 2.60$ & $79.00 \pm 4.04$ & $77.00 \pm 3.46$ & $75.50^{\mathrm{B}}$ & \multirow{4}{*}{0.0025} \\
\hline-20 & $81.00 \pm 2.08$ & $71.00 \pm 2.88$ & $81.67 \pm 2.60$ & $73.67 \pm 2.73$ & $76.92^{\mathrm{B}}$ & \\
\hline-80 & $85.00 \pm 0.00$ & $85.00 \pm 0.00$ & $82.67 \pm 2.33$ & $78.33 \pm 3.28$ & $82.75^{\mathrm{A}}$ & \\
\hline $\begin{array}{l}\text { Overall } \\
\text { mean }\end{array}$ & $79.44^{\mathrm{a}}$ & $76.55^{\mathrm{a}}$ & $81.11^{\mathrm{a}}$ & $76.44^{\mathrm{a}}$ & & \\
\hline Significance & \multicolumn{5}{|c|}{0.1332} & \\
\hline
\end{tabular}

Interaction significance LSD $=0.0996$

Values within the same column with different letters differed significantly at least at $P<0.05$. 
TABLE 4. Effect of freeze - drying media and storage temperature on acrosome integrity $(\%)$ of raw buffalo spermatozoa after freeze-drying.

\begin{tabular}{|c|c|c|c|c|c|c|}
\hline \multirow{2}{*}{$\begin{array}{c}\text { Storage } \\
\text { temperature } \\
\left({ }^{\circ} \mathrm{C}\right)\end{array}$} & \multicolumn{4}{|c|}{ Type of media } & \multirow{2}{*}{$\begin{array}{c}\text { Overall } \\
\text { mean }\end{array}$} & \multirow{2}{*}{$\begin{array}{c}\text { Significa } \\
\text { nce }\end{array}$} \\
\hline & $\begin{array}{c}\text { Tris- } \\
\text { EGTA }\end{array}$ & $\begin{array}{c}\text { Tris- } \\
\text { EDTA }\end{array}$ & TCM & $\begin{array}{c}\text { TCM- } \\
\text { Trehalose }\end{array}$ & & \\
\hline+4 & $55.67 \pm 5.04$ & $59.33 \pm 4.63$ & $72.33 \pm 2.02$ & $59.33 \pm 3.48$ & $61.67^{\mathrm{A}}$ & \multirow{4}{*}{0.2176} \\
\hline-20 & $47.67 \pm 4.41$ & $66.67 \pm 3.48$ & $51.00 \pm 2.64$ & $68.00 \pm 3.46$ & $58.33^{\mathrm{A}}$ & \\
\hline-80 & $58.67 \pm 5.78$ & $67.00 \pm 3.21$ & $56.00 \pm 3.78$ & $71.33 \pm 3.76$ & $63.25^{\mathrm{A}}$ & \\
\hline $\begin{array}{c}\text { Overall } \\
\text { mean }\end{array}$ & $54.00^{\mathrm{b}}$ & $64.33^{\mathrm{a}}$ & $59.78^{\mathrm{ab}}$ & $66.22^{\mathrm{a}}$ & & \\
\hline Significance & \multicolumn{5}{|c|}{0.0042} & \\
\hline
\end{tabular}

Interaction significance LSD $=0.0060$

Values within the same column with different letters differed significantly at least at $P<0.05$.

TABLE 5. Effect of freeze drying media and storage temperature on morghology $(\%)$ of frozen-thawed buffalo spermatozoa after freezedrying.

\begin{tabular}{|c|c|c|c|c|c|c|}
\hline \multirow{2}{*}{$\begin{array}{c}\text { Storage } \\
\text { temperature } \\
\left({ }^{\circ} \mathrm{C}\right)\end{array}$} & \multicolumn{4}{|c|}{ Type of media } & \multirow{2}{*}{$\begin{array}{c}\text { Overall } \\
\text { mean }\end{array}$} & \multirow[b]{2}{*}{ Significance } \\
\hline & Tris-EGTA & $\begin{array}{c}\text { Tris- } \\
\text { EDTA }\end{array}$ & TCM & $\begin{array}{c}\text { TCM- } \\
\text { Trehalose }\end{array}$ & & \\
\hline+4 & $36.33 \pm 2.33$ & $33.33 \pm 4.41$ & $26.00 \pm 6.66$ & $17.00 \pm 2.08$ & $28.17^{\mathrm{A}}$ & \multirow{5}{*}{0.0625} \\
\hline-20 & $24.00 \pm 3.78$ & $18.33 \pm 2.33$ & $18.66 \pm 3.28$ & $27.00 \pm 3.78$ & $22.00^{\mathrm{B}}$ & \\
\hline-80 & $24.66 \pm 3.48$ & $20.00 \pm 2.08$ & $30.66 \pm 3.53$ & $20.00 \pm 2.64$ & $23.83^{\mathrm{AB}}$ & \\
\hline $\begin{array}{c}\text { Overall } \\
\text { mea }\end{array}$ & $28.33^{\mathrm{a}+}$ & $23.89^{\mathrm{ab}}$ & $25.11^{\mathrm{ab}}$ & $21.33^{\mathrm{b}}$ & & \\
\hline Significance & \multicolumn{5}{|c|}{0.1451} & \\
\hline
\end{tabular}

Interaction significance LSD $=0.0111$

Values within the same column with different letters differed significantly at least at $P<0.05$

TABLE 6. Effect of freeze - drying media and storage temperature on membrane integrity $(\%)$ of frozen-thawed buffalo spermatozoa after freeze- drying.

\begin{tabular}{|c|c|c|c|c|c|c|}
\hline \multirow{2}{*}{$\begin{array}{c}\text { Storage } \\
\text { temperature } \\
\left({ }^{\circ} \mathrm{C}\right)\end{array}$} & \multicolumn{4}{|c|}{ Type of media } & \multirow{2}{*}{$\begin{array}{c}\text { Overall } \\
\text { mean }\end{array}$} & \multirow{2}{*}{ Significance } \\
\hline & $\begin{array}{l}\text { Tris- } \\
\text { EGTA }\end{array}$ & $\begin{array}{l}\text { Tris- } \\
\text { EDTA }\end{array}$ & TCM & $\begin{array}{c}\text { TCM- } \\
\text { Trehalose }\end{array}$ & & \\
\hline+4 & $51.00 \pm 3.21$ & $46.66 \pm 10.14$ & $48.33 \pm 8.82$ & $49.33 \pm 8.68$ & $48.83^{B}$ & \multirow{5}{*}{0.0119} \\
\hline-20 & $53.33 \pm 5.21$ & $58.33 \pm 5.04$ & $54.67 \pm 3.38$ & $61.00 \pm 1.53$ & $56.83^{\mathrm{AB}}$ & \\
\hline-80 & $62.67 \pm 3.28$ & $64.00 \pm 3.46$ & $61.67 \pm 4.33$ & $60.33 \pm 5.36$ & $62.17^{\mathrm{A}}$ & \\
\hline $\begin{array}{c}\text { Overall } \\
\text { mean }\end{array}$ & $55.67^{\mathrm{a}}$ & $56.33^{\mathrm{a}}$ & $54.89^{\mathrm{a}}$ & $56.89^{\mathrm{a}}$ & & \\
\hline Significance & \multicolumn{5}{|c|}{0.9771} & \\
\hline
\end{tabular}

Interaction significance LSD $=0.9615$

Values within the same column with different letters differed significantly at least at $P<0.05$.

Egypt. J. Vet. Sci. Vol. 47, No.1 (2016) 
THE EFFECT OF FREEZE DRYING USING DIFFERENT...

TABLE 7. Effect of freeze- drying media and storage temperature on viability $(\%)$ of frozen- thawed buffalo spermatozoa after freeze- drying.

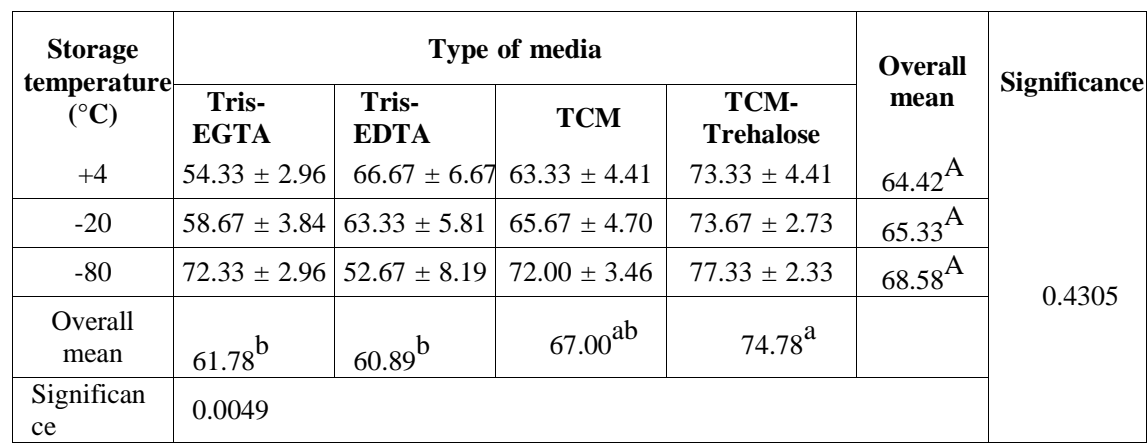

Interaction significance LSD $=0.0739$

Values within the same column with different letters differed significantly at least at $P<0.05$.

TABLE 8. Effect of freeze- drying media and storage temperature on acrosome integrity $(\%)$ of frozen- thawed buffalo spermatozoa thawed buffalo spermatozoa after freeze-drying.

\begin{tabular}{|c|c|c|c|c|c|c|}
\hline \multirow{2}{*}{$\begin{array}{c}\text { Storage } \\
\text { temperature } \\
\left({ }^{\circ} \mathrm{C}\right)\end{array}$} & \multicolumn{4}{|c|}{ Type of media } & \multirow{2}{*}{$\begin{array}{c}\text { Overal } \\
1 \\
\text { mean }\end{array}$} & \multirow[b]{2}{*}{ Significance } \\
\hline & $\begin{array}{l}\text { Tris- } \\
\text { EGTA }\end{array}$ & $\begin{array}{c}\text { Tris- } \\
\text { EDTA }\end{array}$ & TCM & $\begin{array}{c}\text { TCM- } \\
\text { Trehalose }\end{array}$ & & \\
\hline+4 & $45.67 \pm 2.73$ & $65.33 \pm 2.96$ & $54.00 \pm 3.46$ & $62.00 \pm 3.21$ & $56.75^{\mathrm{B}}$ & \multirow{5}{*}{0.0013} \\
\hline-20 & $64.00 \pm 3.60$ & $55.33 \pm 5.61$ & $49.67 \pm 3.53$ & $56.33 \pm 3.84$ & $56.33^{\mathrm{B}}$ & \\
\hline-80 & $65.67 \pm 3.48$ & $74.67 \pm 3.76$ & $76.00 \pm 3.21$ & $48.33 \pm 4.63$ & $66.17^{\mathrm{A}}$ & \\
\hline $\begin{array}{c}\text { Overall } \\
\text { mean }\end{array}$ & $58.56^{\mathrm{b}}$ & $65.11^{\mathrm{a}}$ & $59.89^{\mathrm{ab}}$ & $55.56^{\mathrm{b}}$ & & \\
\hline Significance & \multicolumn{5}{|c|}{0.0331} & \\
\hline
\end{tabular}

Interaction significance LSD $=0.0001$

Values within the same column with different letters differed significantly at least at $P<0.05$

\section{Discussion}

The sperm plasma membrane and acrosome integrities are highly susceptible to injuries, due to loss of water during dehydration (Sherman, 1954, Yushchenko, 1957, Kusakabe et al., 2001, McGinnis et al., 2005 and Kawase \& Suzuki, 2011). Water loss from phospholipid head groups in cell membranes could be due to lateral phase separation resulting in extravasation of intracellular contents (Crowe et al., 1997). In the current study, we found out new data concerning the degree of protection of structural and functional characteristics of the buffalo bull sperm using various freeze-drying media and storage temperatures. We investigated that medium containing trehalose sufficiently protected the membrane and acrosome of buffalo bull sperm. This come in agreement with Martins et al. (2007) in bovine, who stated that freeze-drying medium containing EGTA or trehalose adequately preserved bovine sperm viability during the freeze-drying process, though of the mechanism and function of these solutions in protecting the sperm 
are not clear till now. Our results also are in accordance with Hirabayashi et al. (2005) in rats and Zăhan et al. (2014) in boar. In addition, we found that storage temperature $\left(-80\right.$ and $\left.-20^{\circ} \mathrm{C}\right)$ were the best in preservation of acrosome and sperm membrane comparing to storage at $\left(4^{\circ} \mathrm{C}\right)$. These findings are in accordance with Kawase and Suzuki (2011) who stated that freeze dried sperm stored at $-80^{\circ} \mathrm{C}$ with or without transportation can maintain their ability to generate viable offsprings for long time. Our investigation on sperm freeze-drying revealed no motility. These results come in accordance with Martins et al., 2007, Magalhães et al., 2012, Hara et al., 2014 and Zăhan et al., 2014. In conclusion, we demonstrated that the freeze-drying medium containing trehalose and the storage temperature $\left(-80^{\circ} \mathrm{C}\right)$ and $\left(-20^{\circ} \mathrm{C}\right)$ could preserve efficiently buffalo bull sperm vitality, especially the acrosome, sperm membrane integrity and morphology.

Acknowledgement: The authors are greatly indebted to the National Research Centre and Animal Reproduction Research Institute for sponsoring this work and also greatly indebted to RSTDG for their financial support through the project entitled: "Trials for freeze-drying of bull semen " ID 12655, also thanks are due to the team assistants in the project for their help.

\section{References}

Abdalla, H., Hirabayashi, M. and Hochi, S. (2009) The ability of freeze-dried bull spermatozoa to induce calcium oscillations and resumption of meiosis. Theriogenology, 71, 543-552.

Bialy, G. and Smith, V.R. (1957) Freeze-drying of bovine spermatozoa. J. Dairy Sci., 40, 739-745.

Campbell, R.C., Dott, H.M. and Glover, T.D. (1956) Nigrosin-Eosin as a stain for differentiating live and dead spermatozoa. J. Agric. Sci., 48, 1-8.

Choi, Y.H., Varner, D.D., Love, C.C., Hartman, D.L. and Hinrichs, K. (2011) Production of live foals via intracytoplasmic injection of lyophilized sperm and sperm extract in the horse. Reproduction, 142, 529-538.

Critser, J.K., Huse-Benda, A.R., Aaker, D., Arneson, B.W. and Ball, G.D. (1987) Cryopreservation of human spermatozoa. I. Effects of holding procedure and seeding on motility, fertilizability, and acrosome reaction. Fertil. Steril., 47, 656-663.

Crowe, J.H., Crowe, L.M., Carpenter, J.F., Prestelski, S.J. and Hoekstra, F.A. (1997) Anhydrobiosis: cellular adaptations to extreme dehydration. In: Dantzler WH, editor. Handbook of Comparative Physiology, II. Oxford: Oxford University Press. pp. 1445-1477.

Foote, R.H. (1970) Fertility of bull semen at high extension rates in Tris buffered extenders. J. Dairy Sci., 53, 1475-1477.

Gil, L., Olaciregui, M., Luño, V., Malo, C., González, N. and Martínez, F. (2014) Current Status of Freeze-Drying Technology to Preserve Domestic Animals Sperm. Review Article. Reprod. Dom. Anim., 49, 72-81.

Egypt. J. Vet. Sci. Vol. 47, No.1 (2016) 
Hirabayashi, M., Kato, M., Ito, J. and Hochi, S. (2005) Viable rat offspring derived from oocytes intracytoplasmically injected with freeze dried sperm heads. Zygote, 13,79-85.

Hara, H., Tagiri, M., Hwang, I., Takahashi, M., Hirabayashi, M. and Hochi, S. (2014) Adverse effect of cake collapse on the functional integrity of freeze-dried bull spermatozoa. Cryobiology, 68, 354-360.

Jeyendran, R.S., Van Derv Ven, H.H., Perez-Pelaes, M., Crabo, B.G. and Zaneveld, L.J.D. (1984) Development of an assay the functional integrity of human sperm membrane and its relationship to other semen characteristics. J. Reprod. Fertile., 70, 219-228.

Kaneko, T., Whittingham, D.G. and Yanagimachi, R. (2003) Effect of pH value of freeze-drying solution on the chromosome integrity and developmental ability of mouse spermatozoa. Biol. Reprod., 68, 136-139.

Kaneko, T. and Serikawa, T. (2012) Long-term preservation of freeze-dried mouse spermatozoa. Cryobiology, 64, 211-214.

Kawase, Y. and Suzuki, H. (2011) A study on freeze drying as a method for preserving mouse sperm. J. Reprod. Dev., 57, 176-182.

Keskintepe, L., Pacholczyk, G., Machnicka, A., Norris, K., Curuk, M.A. and Khan, I. (2002) Bovine blastocyst development from oocytes injected with freeze-dried spermatozoa. Biol. Reprod., 67,409-415.

Kovács, A. and Foote, R.H. (1992) Viability and acrosome staining of bull, boar and rabbit spermatozoa. Biotech. Histochem., 67, 119-124.

Kusakabe, H., Szczygiel, M.A., Whittingham, D.G. and Yanagimachi, R. (2001) Maintenance of genetic integrity in frozen and freeze-dried mouse spermatozoa. Proc. Nat. Acad. Sci. USA, 98, 13501-13506.

Kusakabe, H. and Kamiguchi, Y. (2004) Chromosomal integrity of freeze dried mouse spermatozoa after 137Cs gamma-ray irradiation. Mutat. Res., 556, 163-168.

Kwon, I.K., Park, K.E. and Niwa, K. (2004) Activation, pronuclear formation, and development in vitro of pig oocytes following intracytoplasmic injection of freezedried spermatozoa. Biol. Reprod., 71, 1430-1436.

Liu, J.L., Kusakabe, H., Chang, C.C., Suzuki, H., Schmidt, D.W., Julian, M., Pfeffer, R., Bormann, C.L., Tian, X.C., Yanagimachi, R. and Yang, X. (2004) Freezedried sperm fertilization leads to full-term development in rabbits. Biol. Reprod., 70, 1776-1781.

Magalhães, L.C.O., Melo-Oña, C.M., Sudano, M.J., Paschoal, D.M., Crocomo, L.F., Ackermann, C.L., Landim-Alvarenga, F.C. and Lopes, M.D. (2012) Preservation of wild feline semen by freeze-drying: experimental model. Animal Reprod., 9, 201-204. 
Martins, C.F., Báo, S.N., Dode, M.N., Correa, G.A. and Rumpf, R. (2007) Effects of freeze-drying on cytology, ultrastructure, DNA fragmentation and fertilizing ability of bovine sperm. Theriogenology, 67, 1307-1315.

McGinnis, L.K., Zhu, L., Lawitts, J.A., Bhowmick, S., Toner, M. and Biggers, J.D. (2005) Mouse sperm desiccated and stored in trehalose medium without freezing. Biol. Reprod., 73, 627-633.

Parrish, J.J., Krogenaes, A. and Susko-Parrish, J.L. (1995) Effect of bovine sperm separation by either swim-up and percoll method on success of in vitro fertilization and early embryonic development. Theriogenology, 44, 859-869.

Polge, C., Smith, A.U. and Parkes, A.S. (1949) Revival of spermatozoa after vitrification and dehydration at low temperature. Nature, 164, 666-667.

SAS (2008) Statistical analysis system: User's guide v. 9.2: Inst. Inc., Cary N.C., USA.

Sherman, J.K. (1954) Freezing and freeze-drying of human spermatozoa. Fertil. Steril., 5, 357-371.

Wakayama, T., Whittingham, D.G. and Yanagimachi, R. (1998) Production of normal offspring from mouse oocytes injected with spermatozoa cryopreserved with or without cryoprotection. J. Reprod. Fertil., 112, 11-17.

Wakayama, T. and Yanagimachi, R. (1998) Development of normal mice from oocytes injected with freeze-dried spermatozoa. Nat. Biotechno., 16, 639-641.

Way, A. L., Hnault, M.A. and Killian, G.J. (1995) Comparsion of four staining methods for evaluating acrosome ststus and viability of ejaculated and cauda epididymal bull spermatozoa. Theriogenology, 43, 1301-1316.

Yushchenko, N.P. (1957) Proof of the possibility of preserving mammalian spermatozoa in a dried state. Proc. Lenin. Acad. Agr. Sci., 22, 37-40.

Zăhan, M., Moldovan, C., Dascăl, A. S., Hettig, A., Miclea, I., Orlovschi, D. and Miclea, V. (2014) Boar sperm preservation by freeze-drying. Porcine Research, 4 (1), $1-6$. 


\section{تأثير التجميد المجفف للسائل المنوي لطلائق الجاموس على بعض خصائص الحيوان المنوي}

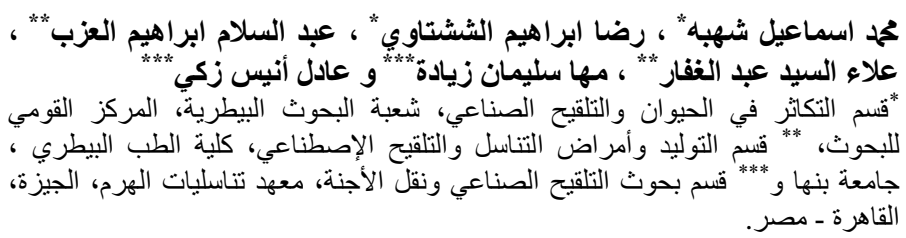

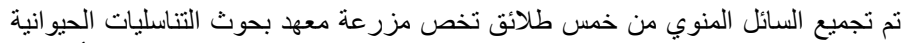

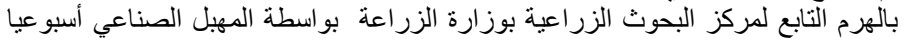

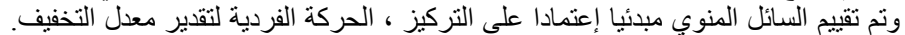

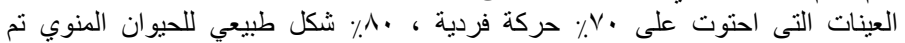

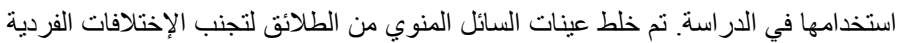

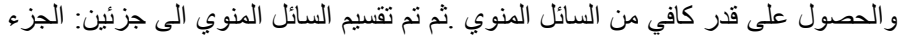

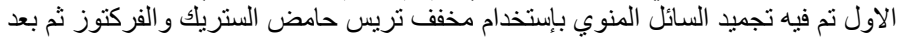

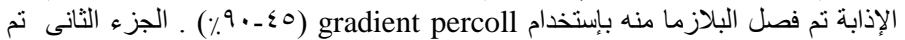

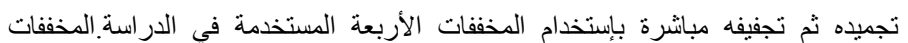

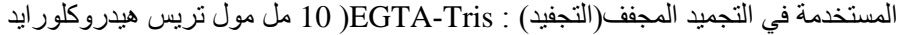

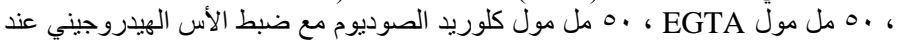

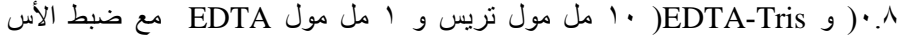

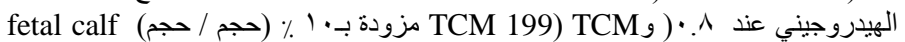

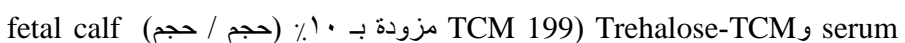
و Y serum

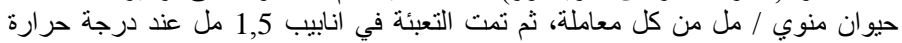

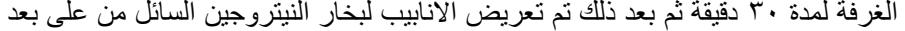

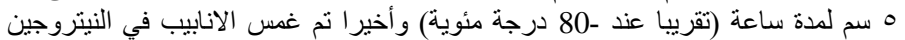

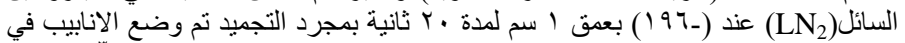

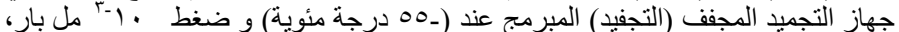

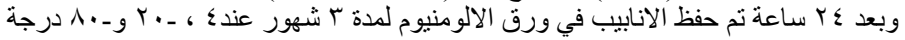

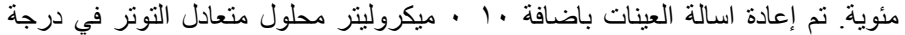

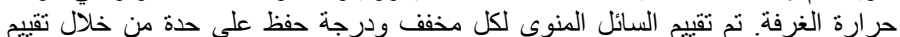

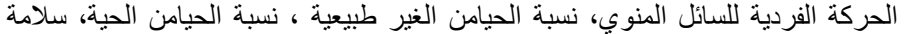

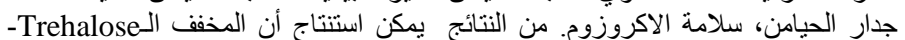

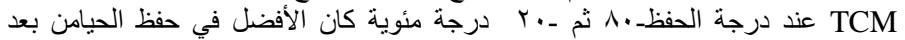

